tiza acerca del teatro moderno español. No parece aventurado suponer que el New Monthly Magazine de i824, en donde apareció la poesía traducida por Espronceda, anduviera en manos de emigrados españoles.

Princenton University.

Vigente LLORENS

\title{
MÁS SOBRE LA MÚSICA EN GERVANTES
}

Trompetas bastardas. Las trompetas, sin otra calificación, y las trompetas bastardas e italianas se mencionan en los Hechos del Condestable don Miguel Lucas de Iranzo (edición y estudio de Juan de Mata Carriazo, Madrid, r940). El cronista de los Reyes Católicos, Bernáldez, habla de "trompetas bastardas e chirimías" y Fernández de Oviedo, cronista del príncipe don Juan - el hijo malogrado de los Reyes Católicos-, menciona entre los ministriles del príncipe "cornetas e trompetas bastardas". Las menciones más significativas son las de la Crónica del Condestable, criado del rey don Enrique IV. Se mencionan allí las trompetas a secas con los atabales, dulzainas y chirimías; juntamente con estos instrumentos van también las trompetas bastardas (dos) y las ytalianas (cuatro). Ni éstas ni aquéllas andan solas, ni se juntan con las otras trompetas sin calificación. Se deduce, sin dificultad, que las bastardas y las italianas eran diferentes, pero parece poder deducirse también que ninguna de las dos eran las trompetas "normales". Posiblemente éstas últimas son las que pudieran considerarse españolas. Las bastardas, si, como hemos supuesto (cf. NRFH, V, pág. 74), eran las trompetas circulares o serpentinas que se describen en el tratado Musica Getutscht (I5II), pudieron ser una variedad de las italianas enroscadas, como parece aceptar Pedrell en su Organografía (Barcelona, Igor, pág. 63), aunque luego decida que las bastardas son las españolas. Lo realmente importante no es la fecha del suceso en que los cronistas hacen aparecer tales instrumentos, sino aquella en que escriben ${ }^{\mathbf{1}}$.

Albogues. La filiación del albogue como instrumento de aliento per-

1 Hay unas lyras bastardas, según me comunica don Raimundo Lida, en LeóN Marchante, Obras poéticas pósthumas de ..., tomo II, pág. I66, villancicos compuestos para la Navidad de I676, cit. en Rodríguez Marín, n. 262 a su edición crítica del Rinconete, Madrid, I920, pág. 466:

La zambomba retumbe con la terrañuela; retumbe, retumbe con voces confusas matraca y bandurria; retumbe, retumbe con lyras bastardas pandero y sonajas...

Estas lyras bastardas no tienen relación con las trompetas bastardas, acerca de las cuales hablábamos en $N R F H, \mathrm{~V}$, págs. 74 y sigs.; pero sí con las violas bastardas (cf. NRFH, II, pág. 40) comunes en el siglo xvr: quizá las miges veules, o medias violas mencionadas en el libro de Tirant lo Blanch. 
teneciente a la clase de doble lengüeta (del tipo óboe) parece quedar definitivamente resuelta por un verso del zéjel xLv de Abén Guzmán: "la xalamía procede del albogue" (zulami min al-buq). (A. R. NyкL, El Cancionero de Abén Guzmán, pág. 392, Madrid, 1933.) Nykl traduce zulami por óboe, pero la xalamía, perfectamente conocida por su nombre, es instrumento de doble caña como el $z a m r$, mencionado aquél por Pedrell con los instrumentos graves de la familia (bombardaš y cornamusas, de donde Schalmey en alemán; Pedrell, op. cit., págs. 67,76 y sigs.; Gurt SAGHS, Handbuch der Musikinstrumentenkunde, Leipzig, 1930, pág. 32 I $)^{2}$.

El Colegio de México.

Adolfo Salazar

2 Corríjase en $N R F H$, vol. V, núm. I: págs. 72, línea 25, léase: Tal instrumento; 74, lín. 6: entre otras bujerías; 75 , lín. 7: vuelta externa, antepenúltima: coblas de trompadors; 83 , lín. 2: sino que tan sólo se tamborileaban con los pies, lín. i7: Aquelindo, lín. 45: el ejemplo de música debe llevar una corchea en su tercera nota; 84 , lín. 46: serviría; 86 , líns. 44-45: clavicembalo; 87, lín. 4: hablamos en otro lugar de esta misma revista; 88, lín. 2: llevarlos, lín. 5: trompa de caza. 